\title{
Pengembangan Kinerja Metakognitif Peserta Didik untuk Meningkatkan Kemampuan Pemecahan Masalah Kolaboratif Melalui Penerapan RPP Model Pembelajaran PME
}

\author{
Ihdi Amin ${ }^{1}$, Sukestiyarno², St. Budi Waluya ${ }^{3}, \&$ Sc. Mariani ${ }^{4}$ \\ ${ }^{1}$ SMAN 1 Kersana, Brebes; ihdimathsma@yahoo.com \\ 2Universitas Negeri Semarang, Semarang; sukestiyarno@gmail.com \\ 3Universitas Negeri Semarang, Semarang; budiwmathunnes@yahoo.com \\ 4Universitas Negeri Semarang, Semarang; scmariani.unnes@gmail.com
}

\begin{abstract}
The PME learning model is a model designed to optimize metacognitive learning through planning, monitoring, and evaluating activities (Amin \& Mariani, 2017). This study aims to analyze the effect of applying the PME model Lesson Plan $(L P)$ in the development of metacognitive performance to improve collaborative problem-solving (CPS) abilities in mathematics learning. The subjects were 37 students of Grade XI of Kersana-Brebes 1 Senior High School. The data were collected using student questionnaire and problem solving test. Those were analyzed using paired sample t-test. The analysis included (1) Accomplishment level of PME model LP - a Control Tally Sheet (CTS-PME) was provided to control the level; (2) Students' metacognitive performance - students filled Effectiveness Questionnaire (EQ-PME) adopted from Darling-Hammond's metacognitive strategy; (3) ability of collaborative problem solving - students worked on student's worksheet (SW). The results were: (1) sig. $=0.000<0.05$ and $t$-cal $=-4.820$, - which meant that $L P$ showed significant increase in planning, monitoring and evaluating in learning activities; (2) sig. $=0.000<0.05$ and $t$-cal $=-7.854$. It showed that the LP implemented could increase the students' metacognitive performance; and (3) sig. = $0.001<0.05$ and $t$-cal $=-4.671$. These numbers indicated that the $L P$ could significantly increase students' ability of collaborative problem solving.
\end{abstract}

Keywords: collaborative problem solving, metacognitive, PME model lesson plan

\section{Pendahuluan}

Pembelajaran matematika perlu menekankan pada: (1) aktivitas belajar yang mementingkan pemahaman daripada hanya mengingat prosedur, (2) melatih kemampuan berpikir, (3) melatih keterampilan manipulasi matematika untuk menyelesaikan masalah, (4) melatih keterampilan penalaran matematika, dan (5) pembelajaran berbasis pemecahan masalah (Kemdikbud, 2016). Ketika peserta didik belajar pemecahan masalah, bimbingan yang baik dari lingkungannya dapat menjadi pendorong bagi peserta didik (Gartmann, and Freiberg, 1993). Pemecahan masalah mestinya merupakan aktivitas yang banyak diterapkan dalam matematika dan menjadi hal yang penting dalam pengembangan matematika itu sendiri (Ali dkk, 2010), karena kemampuan pemecahan masalah tidak dapat diciptakan oleh mesin hitung tapi dari faktor pengalaman dan dari keadaan lingkungan yang menuntutnya (Feist \& Feist, 2013: 182).

Menurut Carlson \& Bloom (2005), tugas matematika dipandang sebagai masalah jika: (i) cukup menantang, (ii) mampu menghasilkan berbagai jalur solusi, dan (iii) dapat saja menyebabkan kebuntuan sehingga menimbulkan respon afektif yang kuat. Oleh karena itu, menurut Kaur (dalam Hoe, et al, 2001), kegiatan pemecahan masalah dalam pembelajaran matematika merupakan hal yang sangat sulit dilakukan oleh 
peserta didik. Kesulitan biasanya disebabkan karena: (1) kurangnya pemahaman terhadap masalah; (2) kurangnya pengetahuan tentang pendekatan dan strategi; dan (3) ketidakmampuan menerjemahkan masalah ke dalam bentuk matematika.

Beberapa kajian terkini menyatakan bahwa proses metakognitif sangat berpengaruh terhadap kinerja pemecahan masalah. Davidson et al. (Hoe, et al., 2001) mencatat ada empat proses metakognitif yang berkontribusi penting pada kinerja memecahkan masalah diberbagai domain: (1) mengidentifikasi dan mendefinisikan masalah;

menyajikan secara mental suatu masalah; (3) perencanaan bagaimana untuk melanjutkan; dan (4) mengevaluasi apa yang telah dikerjakan. Menurut Lin (dalam Yimer dan Ellerton., 2006), fungsi metakognitif internal berupa kemampuan mengkontrol situasi merupakan kunci keberhasilan dalam pembelajaran. Gartmann and Freiberg (2012) mengungkapkan bahwa beberapa peserta didik yang mampu menemukan alternatifalternatif pendekatan atau strategi, mereka akan mereka menggunakannya kembali sebagai koreksi (self regulation) jika mereka melakukan dan mendapatkan tugas lagi. Hasil penelitian Amin \& Sukestiyarno (2015) mengungkapkan bahwa meskipun dalam pembelajaran matematika SMA peserta didik memiliki kesadaran metakognitif yang baik, namun kesadaran metakognitif tersebut tidak cukup dibarengi dengan: (1) kemampuan dalam mengingat informasi dan kemampuan untuk menilai sendiri dalam memahami sesuatu; (2) kecepatan dalam menemukan strategi pembelajaran dan kemampuan untuk menentukan strategi yang paling efektif; (3) kesadaran untuk mengatur studi agar memiliki waktu belajar lebih lama; (4) kemampuan dalam membuat gambar, dan menggunakan peta konsep yang dapat membantu pemahaman; (5) kesadaran untuk menganalisis kegunaan strategi pada saat mereka belajar; (6) kemampuan dalam mengevaluasi langkah-langkah pada saat menghadapi kebingungan; (7) kesadaran untuk membuat ringkasan; dan (8) kemampuan dalam melakukan analisis kinerja dan efektivitas strategi setelah selesai belajar. Hal ini yang menyebabkan peserta didik cenderung mengalami kegagalan pada kegiatan pemecahan masalah.

Pada penelitian berikutnya berkenaan dengan keterlaksanaan kerangka kerja pemecahan masalah, Amin dan Sukestiyarno (2015) mengungkapkan: (1) banyak peserta didik tidak dapat mempertahankan konsistensinya pada rasa ingin tahu ketika berhadapan dengan masalah; (2) kebutuhan pada bantuan orang lain ketika akan memutuskan strategi mana yang akan dipilih; (3) peserta didik kesulitan dalam menyusun langkah-langkah penyelesaian dan menemukan beberapa strategi penyelesaian masalah; (4) respon emosional peserta didik masih lemah ketika berhadapan dengan situasi pemecahan masalah, dan (5) peserta didik jarang sekali melakukan refleksi dan evaluasi mengenai efisiensi dan efektivitas proses kognitif yang dilakukannya. Deskripsi di atas menunjukkan bahwa sangat penting melakukan kegiatan pembelajaran pemecahan masalah dalam pembelajaran matematika melalui peningkatan kinerja metakognitif peserta didik.

Kurikulum 2013 menekankan empat macam kompetensi yang bersifat generik yang direpresentasikan dalam sikap spiritual, sikap sosial, pengetahuan, dan keterampilan. Pemberlakuan kurikulum 2013 tersebut menuntut adanya perubahan paradigm pembelajaran. 
Karena Lesson plan atau RPP menurut Jones (1998), merupakan inti dari refleksivitas yang mencakup pertanyaan-pertanyaan mendasar tentang apa yang guru maksudkan agar para peserta didik belajar dan bagaimana tujuan pembelajaran akan dicapai. Namun demikian, dalam faktanya banyak terjadi benturan antara format perencanaan pelajaran beserta pendekatan yang direkomendasikan dengan beberapa format yang dibutuhkan secara empiris (John, 2006). Sehingga dibutuhkan kejelian guru dalam menyusun RPP yang memenuhi standar tuntutan kurikulum dan mempunyai tingkat keterlaksanaan yang tinggi. Penelitian ini menawarkan format dan kegiatan pembelajaran yang dilaksanakan dengan model pembelajaran Planning-Monitoring-Evaluating (PME), dan selanjuntnya disebut RPP Model Pembelajaran PME.

Penelitian ini bertujuan menguji dan menganalisis efek penerapan RPP model pembelajaran PME dalam mengembangkan kinerja metakognitif untuk meningkatkan kemampuan pemecahan masalah kolaboratif peserta didik. Rumusan masalah yang ingin dijawab dalam penelitian ini adalah (1) bagaimana efek penerapan RPP model pembelajaran PME dalam meningkatkan aktivitas planning, monitoring, dan evaluating pada kegiatan pembelajaran matematika SMA, (2) bagaimana implementasikan RPP model pembelajaran PME dapat meningkatkan kinerja metakognitif peserta didik, dan (3) bagaimana efek penerapan RPP model pembelajaran PME dalam meningkatkan kemampuan pemecahan masalah kolaboratif. Indikator keberhasilan yang digunakan untuk menjawab rumusan masalah tersebut berupa: (1) peningkatan kualitas keterlaksanaan model pembelajaran PME yang digambarkan melalui kegiatan planning, monitoring, dan evaluating, (2) peningkatan kinerja metakognitif, dan (3) peningkatan kemampuan pemecahan masalah secara berkelompok.

\section{Kajian Teori}

Menurut Uno (2009), RPP merupakan seperangkat tulisan berisi rencana kegiatan pembelajaran dan/atau praktikum yang harus disiapkan oleh guru. Rencana pembelajaran diperlukan untuk memperbaiki pembelajaran. RPP membantu memastikan bahwa proses pembelajaran sejalan dengan tujuan kurikulum dan tujuan pembelajaran (Duncan \& Met, 2010), dan RPP dapat menjadi ciri profesionalisme guru (Jones, 1998).

Shrawder (2006) menyatakan, perencanaan pengajaran yang baik membantu menyelesaikan tugastugas penting pada pengaturan tujuan dan menggambarkan bagaimana guru akan menjangkaunya. Menurut Duncan \& Met (2010), RPP membantu memastikan bahwa proses pembelajaran sejalan dengan tujuan kurikulum dan tujuan pembelajaran. Pembelajaran yang telah terencana dengan baik memungkinkan peserta didik menjadi pembelajar yang sukses karena pembelajaran tidak hanya membentuk bagaimana dan apa yang dipelajari peserta didik, tetapi juga berdampak pada sikap peserta didik terhadap belajar.

Model pembelajaran PME merupakan konsep model pembelajaran yang menekankan aktivitas planning, monitoring, dan evaluating sebagai fase-fase utama pada kegiatan pembelajaran dan langkah-langkah operasional pada kegiatan pemecahan masalah. Model pembelajaran ini bertujuan mengarahkan proses pembelajaran yang berpusat pada siswa, dapat meningkatkan kemampuan 
pemecahan masalah peserta didik, dapat meningkatkan sikap positif peserta didik, dan dapat meningkatkan kemampuan metakognitif peserta didik (Amin \& Mariani, 2017). Menurut Fogarty (TEAL, 2012), pengajaran metakognisi merupakan sebuah proses yang menjangkau tiga fase berbeda: (1) mengembangkan suatu rencana (plan) sebelum mendekati tugas pembelajaran, (2) memonitor pemahaman dalam menggunakan strategi "fix-up" ketika terjadi kegagalan pemahaman, dan (3) mengevaluasi pemikiran mereka setelah menyelesaikan tugas. Sedangkan Ann Brown et al (dalam Darling-Hammond et al, 2003) mendeskripsikan tiga jalan yang diarahkan pada pengajaran metakognisi, yaitu: (1) merencanakan pendekatan-pendekatan untuk tugas, (2) memonitor aktivitas selama pembelajaran, dan (3) pengecekan hasil.

Menurut Amin \& Mariani (2017), strukturisasi model pembelajaran PME dijabarkan dalam tiga fase pengajaran dengan strategi metakognitif, yaitu planning, monitoring, dan evaluating. Aktivitas pengajaran kontruktivis diimplementasikan dalam empat tahapan pengajaran, yakni tahapan pendahuluan, tahapan eksplorasi, tahapan refleksi; serta tahapan aplikasi dan diskusi. Sedangkan sistem pendukung yang dirancang sebagai penjamin efektivitas model pembelajaran PME meliputi RPP atau RPP, lembar kerja peserta didik (LKPD) dan lembar kendali keterlaksanaan PME (LKK-PME). RPP model pembelajaran PME memuat kegiatan pembelajaran yang terbagi tiga tahapan yaitu tahapan kegiatan persiapan/pengantar, tahapan kegiatan inti, dan tahapan kegiatan penutup. Tahapan kegiatan persiapan/pengantar (start) memuat tiga ruang lingkup kegiatan yaitu: kegiatan pengkondisian pembelajaran dan penyiapan sarana pembelajaran, kegiatan penyiapan mental peserta didik dalam pembelajaran, dan kegiatan mengukur pengetahuan awal atau prasyarat peserta didik. Tahapan kegiatan inti memuat kegiatan eksporasi, refleksi, aplikasi dan diskusi) dan proses pembelajaran juga dibagi dalam tiga fase, yaitu (1) fase planning, berisi aktivitas penyiapkan dan proses transfer pengetahuan baru, (2) fase monitoring berisi aktivitas refleksi melalui aktivitas pemecahan masalah secara kolaboratif yang dilaksanakan dalam tiga fase, yaitu planning, monitoring, dan evaluating, dan (3) fase evaluating berisi kegiatan penilaian terhadap hasil pemikiran dan pemahaman melalui kegiatan presentasi, memperhatikan masukan dari kelompok lain atau guru, dan melakukan revisi (revising). Tahapan kegiatan penutup memuat kegiatan konfirmasi terhadap topik baru, melakukan upaya pengkondisian untuk pembelajaran berikutnya, dan kegiatan refleksi diri melalui pengisian LKK-PME. LKK-PME merupakan bagian dari RPP yang dirancang untuk mengendalikan kegiatan pembelajaran dengan strategi metakognitif dalam kerangka planning, monitoring, dan evaluating.

Menurut Darling-Hammond (2003), beberapa strategi yang berpeluang merefleksikan pembelajaran, mengatur cara belajar, dan mengarahkan belajar peserta didik antara lain: (1) predicting outcome, berguna membantu peserta didik memahami jenis informasiyang dibutuhkan dalam kegiatan pemecahan masalah; (2) evaluating work, yakni melatih peserta didik meninjau pekerjaan mereka dan menentukan di mana kekuatan dan kelemahan mereka; (3) questioning by the teacher, yakni guru bertanya kepada peserta didik saat mereka bekerja; (4) self-assessing, yakni 
mendorong peserta didik merefleksikan pembelajaran mereka dan menentukan seberapa baik mereka telah belajar; (5) selfquestioning, yakni peserta didik diajak mengajukan pertanyaan dari diri sendiri dan menggunakan pertanyaan untuk memeriksa pengetahuan mereka sendiri saat mereka belajar; (6) selecting strategies, yakni mengajak peserta didik memutuskan strategi mana yang berguna untuk tugas yang diberikan; (7) using directed or selective thinking, yakni mengajak peserta didik memilih secara sadar untuk mengikuti garis pemikiran tertentu atau pendekatan terstruktur untuk menemukan jawabannya; (8) using discourse, yakni mengajak peserta didik mendiskusikan gagasan yang membuat berpikir lebih konkret dan belajar untuk mengajukan pertanyaan, mengidentifikasi kesenjangan dalam pengetahuan mereka sendiri, dan belajar dari pikiran dan ide orang lain; (9) critiquing, yakni mendorong peserta didik memberikan umpan balik kepada peserta didik lain dengan cara yang konstruktif; dan (10) revising, yakni menajak peserta didik kembali ke pekerjaan mereka setelah menerima umpan balik.

\section{Metode Penelitian}

Indikator kerja instrumen LKK-PME diadopsi dari tiga tahapan utama model pembelajaran PME yaitu planning, monitoring, dan evaluating (Amin \& Mariani, 2017), sedangkan indicator kerja instrumen KEMP-PME diadopsi dari sepuluh tahapan strategi metakognitif menurut Darling-Hammond (2003). Data dianalisa menggunakan paired sample t-test untuk mengetahui perbedaan kondisi data pada sampel yang berpasangan, yakni kondisi sebelum dikenai perlakuan dan setelah dikenai perlakuan.
Ruang lingkup penelitian ini adalah pengembangan kinerja metakognitif peserta didik yang berimplikasi terhadap meningkatkan kemampuan pemecahan masalah secara kolaboratif pada pembelajaran matematika SMA sebagai efek dari penerapan RPP dengan model pembelajaran PME. Populasi penelitian adalah peserta didik kelas XI SMAN 1 Kersana, dengan sampel penelitian yang dipilih adalah peserta didik kelas XI.MIPA.3 SMA Negeri 1 Kersana yang terdiri dari 37 peserta didik. Data penelitian diperoleh melalui angket/kuesioner peserta didik dan tes kemampuan pemecahan masalah.

Variabel penelitian yang hendak diukur meliputi: (1) keterlaksanaan RPP model pembelajaran PME, (2) kinerja metakognitif, dan kemampuan pemecahan masalah secara kolaboratif. Instrumen yang digunakan untuk mengukur variabel penelitian meliputi: (1) LKK-PME untuk mengkontrol sekaligus mengukur tingkat keterlaksanaan RPP model pembelajaran PME, (2) Kuesioner Efektivitas Model Pembelajaran PME (KEMP-PME) untuk mengukur kinerja metakognitif peserta didik dalam kegiatan pembelajaran, dan (3) LKPD untuk mengukur kemampuan pemecahan masalah secara kolaboratif.

\section{Hasil dan Pembahasan}

\subsection{Hasil}

Hasil uji paired sample t-test berkenaan dengan tingkat keterlaksanaan RPP model pembelajaran PME diperoleh nilai sig. $=0.0001<0.05$. Ini menunjukkan bahwa keterlaksanaan RPP model pembelajaran PME secara signifikan memberikan nilai rata-rata yang tidak sama pada kondisi awal dan akhir. Sedangkan nilai $t$-hitung $=-4.820$, yang menunjukkan bahwa kondisi awal keterlaksanaan model pembelajaran PME memiliki nilai 
rata-rata lebih rendah dari kondisi akhir.

Hasil uji paired sample t-test berkenaan dengan kinerja metakognitif peserta didik sebagai efek dari penerapan RPP model pembelajaran PME diperoleh nilai sig. $=0.0001<0.05$. Ini menunjukkan bahwa kinerja metakognitif secara signifikan memberikan nilai rata-rata yang tidak sama pada kondisi awal dan akhir. Sedangkan nilai $t$-hitung $=-7.854$, yang menunjukkan bahwa kondisi awal kinerja metakognitif peserta didik memiliki nilai rata-rata lebih rendah dari kondisi akhir.

Hasil uji paired sample t-test berkenaan dengan kemampuan pemecahan masalah secara kolaboratif sebagai efek dari penerapan RPP model pembelajaran PME diperoleh nilai sig. $=0.001$ $<0.05$. Ini menunjukkan bahwa kemampuan pemecahan masalah secara kolaboratif memberikan nilai rata-rata yang tidak sama pada kondisi awal dan akhir. Sedangkan nilai $t$-hitung $=-4.671$, yang menunjukkan bahwa kondisi awal kemampuan pemecahan masalah peserta didik secara kolaboratif memiliki nilai rata-rata lebih rendah dari kondisi akhir.

\subsection{Pembahasan}

Pengembangan model pembelajaran PME dimaksudkan untuk menjawab tuntutan pemberlakuan kurikulum 2013 di Indonesia yakni terjadinya pencapaian kemampuan metakognitif dan pemecahan masalah. Penerapan RPP model PME dilakukan dengan menempatkan strukturisasi model pembelajaran PME dan sistem pendukungnya sebagai bagian utama dari RPP yang disusun. Hasil pada penelitian ini menunjukkan bahwa peningkatan kualitas pelaksanaan RPP model pembelajaran PME secara signifikan dapat meningkatkan kinerja metakognitif peserta didik.
Penerapan kualitas pelaksanaan RPP yang ditandai dengan adanya peningkatan nilai rata-rata keterlaksanaan RPP yang diukur dengan LKK-PME. Peningkatan ini juga menandai terjadinya peningkatan kinerja metakognitif peserta didik, baik secara individu maupun kelompok. Beberapa hal yang menyebabkan terjadinya penerapan kinerja metakognitif peserta didik adalah karena peserta didik "diatur" dan "dipaksa" untuk melakukan: (1) kegiatan mandiri peserta didik (self-activities) untuk membangun pengetahuan dasar mereka melalui kegiatan eksplorasi dan elaborasi pada fase planning, (2) kegiatan pemecahan masalah secara kolaboratif pada fase monitoring, dan (3) kegiatan self-evaluation melalui pengisian LKK-PME pada fase evaluating. Hal ini selaras dengan pendapat Okoza \& Aluede (2013) bahwa metakognisi berti mendorong seseorang untuk mengontrol, mengatur atau mengarahkan kegiatan melalui pengaturan dan pemaksaan diri selama belajar dan dalam situasi yang berbeda.

Kegiatan mandiri peserta didik (selfactivities) dilakukan melalui kegiatan menulis

(menyusun ikhtisar/overview), mencari contoh dan pembahasan, kemudian dilanjutkan dengan mengerjakan soal latihan secara mandiri. Kegiatan menyusun overview telah mendorong peserta didik mengeksplorasi pengetahuan dari berbagai sumber belajar atau referensi sesuai dengan tingkat kemampauan dasar yang mereka miliki. Kegiatan mencari contoh dan pembahasan membantu peserta didik memahami konsep (pengetahuan dasar) yang diperolehnya pada overview yang dibuatnya. Sedangkan kegiatan mengerjakan soal latihan secara mandiri dapat digunakan untuk menguji secara mandiri sejauh mana pemahaman peserta didik terhadap 
hasil eksplorasi yang telah dilakukannya. Ketiga kegiatan mandiri tersebut menjadi rangkaian kegiatan pada fase planning yang menjadikan peserta didik lebih mapan dalam mengikuti pembelajaran di kelasnya meskipun pada tingkat yang berbeda-beda sesuai dengan kesungguhan mereka dalam melakukan eksplorasi. Menurut Joyce et al (2009), metakognitif juga berhubungan dengan konstruktivisme dalam hal bahwa banyak peserta didik yang efektif makin sadar bagaimana mereka belajar.

Pada fase monitoring, peserta didik didorong dan dibimbing melakukan dengan pemecahan masalah secara kolaboratif, sehingga kajian berikutnya dari penelitian ini terkait dengan efek penerapan RPP terhadap kemampuan pemecahan masalah secara kolaboratif. Menurut Schneider dan Lockl (2002), metakognisi juga merupakan suatu bentuk kemampuan eksekutif yang melibatkan pemantauan dan pengendalian. Hasil penelitian menunjukkan bahwa penerapan RPP model pembelajaran PME efektif yang berorientasi pada kinerja metakognitif secara signifikan berhasil meningkatkan kemampuan pemecahan masalah peserta didik secara kolaboratif. Menurut Ali et al. (2010), menyajikan pemecahan masalah pada peserta didik berarti memberi kesempatan peserta didik untuk belajar mengambil risiko, mengadopsi pemahaman baru, menerapkan pengetahuan, bekerja dalam konteks, dan menikmati sensasi menjadi penemu. Sedangkan Schoenfeld menganggap bahwa pemecahan masalah berarti mempromosikan self-regulation. Kegiatan pemecahan masalah memberi peluang ideal untuk meningkatkan strategi metakognitif dan peserta didik dengan kemampuan metakognitif unggul lebih baik dalam hal pemecahan masalah (Toit, 2009).

Kegiatan pemecahan masalah secara kolaboratif pada model pembelajaran PME digunakan untuk memonitor seberapa baik pengetahuan yang telah dimiliki masing-masing peserta didik dari kegiatan eksplorasi dan elaborasi (pada fase planning) dan untuk meminimalisir kesenjangan antar peserta didik. Dengan bekerja secara kolaboratif pada kelompok heterogen, akan tercipta komunikasi yang lebih dekat dan intens antara peserta didik dengan kemampuan yang berbeda-beda, sehingga proses transfer knowledge berjalan dengan lebih efektif. Menurut Yin \& Abdullah (2013), pemecahan masalah kolaboratif mensyaratkan bahwa masalah diselesaikan dalam kelompok dan bukan hanya oleh kemampuan individu. Hal ini disebabkan oleh kurangnya pengalaman, perspektif dan pengetahuan individu yang berbeda dan tingkat pengalaman tentang hal yang berbeda, Sedangkan menurut $\mathrm{H}$. Mclellan (Lu and Lin, 2017), pemecahan masalah secara kolaboratif mempunyai tujuan tidak hanya mencakup pengembangan keterampilan pemecahan masalah tetapi juga membimbing pengembangan kerjasama dan kemampuan komunikasi peserta didik. Dalam kelompok heterogen, kemampuan dan perspektif individu terbatas, sehingga untuk menemukan solusi yang tepat terhadap suatu masalah sangat dibutuhkan kerja sama di antara anggota kelompok dan bahkan pada mereka yang memiliki pandangan berbeda. Hasil penelitian Johnston dkk. (dalam Yin \& Abdullah, 2013) mengungkapkan bahwa pemecahan masalah secara kolaboratif merupakan salah satu metode pembelajaran aktif yang dapat menstimulasi pembelajaran. Kegiatan yang dilakukan dapat meningkatkan keterampilan 
komunikasi dan keterampilan kerja kelompok. Pembelajaran kolaboratif membantu peserta didik mengintegrasikan ide-ide baru untuk belajar secara mendalam. Ini juga diperkuat oleh hasil penelitian Hurme (2010) yang menyatakan bahwa proses metakognisi yang dibagi secara sosial adalah pembeda dalam keberhasilan pemecahan masalah matematika kelompok. Metakognisi yang dibagikan secara sosial mengharuskan anggota grup berpartisipasi dalam pemecahan masalah bersama secara sengaja dan timbal balik, saling mengakui pemikiran satu sama lain dan mengembangkan ide mereka lebih lanjut. Dengan kata lain, proses metakognisi yang dibagi secara sosial memiliki niat untuk mengarahkan diskusi daripada bertukar pikiran tentang cara-cara yang mungkin untuk menyelesaikan tugas. Proses metakognisi yang dibagi secara sosial akan dapat mengurangi perasaan kesulitan peserta didik, memupuk kesuksesan dalam pemecahan masalah kelompok, dan membantu pemikiran individu tumbuh sebagai bagian dari grup.

Pada fase evaluating, peserta didik diatur dan dipaksa melakukan kegiatan konfirmasi, merevisi terhadap produk akhir, melakukan penerapan pengetahuan melalui kinerja mandiri, dan selanjutnya diakhiri dengan kegiatan selfevaluation berbantuan Lembar Kendali Keterlaknaan Planning, Monitoring, dan Evaluating (LKKPME). Peserta didik didorong dan dibimbing membuat revisi-revisi dan catatan-catatan tambahan untuk menyempurnakan pengetahuan yang perolehnya dari kegiatan eksplorasi, elaborasi, dan pemecahan masalah. Sedangkan kegiatan self-evaluation dilakukan untuk mengukur, mengontrol, dan meningkatkan kinerja metakognitif peserta didik. Jadi pada model pembelajaran PME, instrumen LKK-PME merupakan instrumen yang sangat penting untuk menjaga dan mengontrol proses kinerja metakognitif. Dengan meminta peserta didik mengisi LKKPME berarti buru telah meminta peserta didik menilai diri sendiri tentang sejauh mana kualitas planning, monitoring, dan evaluating yang dilakukannya selama pembelajaran. Ketika guru dapat menjaga motivasi belajar peserta didik, mengisi LKK-PME akan mendorong peserta didik terus berupaya meningkatkan kualitas pembelajaran mereka. Menurut Muijs \& Reynolds (2008), guru perlu mengingatkan peserta didik untuk mengevaluasi proses-proses metakognitif yang diterapkan dalam menyelesaikan masalah, dan dalam pandangan Meichenbaum (TEAL, 2012) metakognisi menawarkan kesadaran seseorang pada pengetahuan dirinya dan kemampuan seseorang untuk memahami, mengontrol, dan memanipulasi proses kognitif dirinya.

Hasil penelitian ini juga menunjukkan bahwa implementasi penerapan RPP model pembelajaran PME berhasil meningkatkan kinerja metakognitif di kelas pembelajaran matematika. Peningkatan yang tertinggi dihasilkan pada kemampuan self-assessing, using directed or selective thinking, questioning to the teacher, dan revising. Peningkatan kemampuan self-assessing dipengaruhi oleh kegiatan peserta didik mengisi LKK-PME pada fase evaluating, yang sengaja dirancang untuk mengontrol kinerja metakognitif peserta didik. Peningkatan kemampuan using directed or selective thinking dipengaruhi oleh kegiatan eksplorasi dan elaborasi yang dilakukan pada fase planning. Ketika melakukan eksplorasi dan elaborasi, peserta didik didorong untuk menyeleksi dan mengolah informasi yang 
diperolehnya dari berbagai sumber belajar. Peningkatan kemampuan questioning to the teacher dan revising dipengaruhi oleh kegiatan pembelajaran pemecahan masalah kolaboratif pada fase monitoring. Kegiatan kolaboratif ini menjadi sarana bagi peserta didik untuk berdiskusi, mengajukan pertanyaanpertanyaan, atau menjawab pertanyaan. Melalui kegiatan kolaboratif, peserta didik juga lebih mudah dalam melakukan revisi pada bagian-bagian yang masih keliru atau salah.

Peningkatan terendah terjadi pada kemampuan predicting outcome, selfquestioning, selecting strategies, dan critiquing. Berkembangnya keempat kemampuan membutuhkan kemapanan peserta didik pada kemampuan kognitif, kemampuan penalaran, dan pengalaman dalam menyelesaikan soal-soal matematika. Oleh karena itu dibutuhkan proses pembelajaran metakognisi yang lebih panjang, dan pada bagian ini faktor motivasional berkaitan dengan implementasi RPP model pembelajaran PME perlu dijaga dengan sebaik-baiknya. Dalam penelitian sebelumnya, Amin, dkk. (2018) mengungkapkan bahwa (1) rendahnya kemampuan ini sangat dipengaruhi oleh kemampuan predicting outcome; (2) rendahnya kemampuan critiquing disebabkan karena mayoritas peserta didik merasa memiliki penalaran matematika masih terbatas dan penguasaan konsep yang dikuasai masih lemah, sehingga peserta didik menjadi tidak percaya diri atau tidak memiliki keberanian berpendapat untuk menyampaikan ide-ide dan gagasa; (3) rendahnya kemampuan self-questioning ditandai dengan masih rendahnya upaya peserta didik mencari rujukan dan menjawab pertanyaan lain secara mandiri untuk menambah wawasan pengetahuan, dan upaya peserta didik mencari cara terbaik dalam menguasai materi dipelajari dan mencari manfaat atau kegunaan materi yang dipelajarinya.

Keseluruhan deskripsi di atas mengungkapkan bahwa terjadinya penerapan kinerja metakognisi dan pemecahan masalah kolaboratif disebabkan karena pembelajaran dirancang secara sistematis untuk melibatkan intelektual dan kegiatan mental (seperti motivasi, kesadaran, dan kontrol) peserta didik secara optimal. Menurut Lester (2013), pengajaran pemecahan masalah dan metakognisi akan efektif jika diberikan dengan cara yang terorganisir secara sistematis di bawah arahan guru. Sedangkan menurut Darling-Hammond (2003), guru yang ingin mengembangkan keterampilan metakognitif harus berupaya membantu peserta didik menggabungkan refleksi aktif dalam pembelajarannya melalui upaya memodelkan dan men-scaffold proses refleksi, mempertanyakan, mengevaluasi, dan memikirkan strategi-strategi yang mungkin tidak datang secara alami.

Dalam pandangan Joyce dkk (2009), cara penerapan suatu RPP model pembelajaran akan berpengaruh besar terhadap kemampuan peserta didik menjadi para pembelajar yang handal (powerfull learners). Penerapan RPP model pembelajaran PME telah berpengaruh terhadap peningkatan aktivitas planning, monitoring, dan evaluating yang dilakukan oleh peserta didik, karena pembelajaran yang sukses adalah pembelajaran yang mampu melibatkan peserta didiknya dalam tugas-tugas yang sarat dengan muatan-muatan kognitif dan sosial, dan mengajari mereka bagaimana mengerjakan tugas-tugas tersebut secara produktif. Penerapan RPP model pembelajaran PME juga dirasakan mampu mengekspos peserta didik dalam situasi metakognitif yang optimal. Menurut 
Ghasempour et al. (2013) sangat penting bagi guru untuk mengekspos peserta didik dalam situasi metakognitif untuk lebih menerapkan sumber daya kognitif melalui kontrol metakognitif. Camahalan (dalam Toit, 2009) menemukan bahwa prestasi akademik peserta didik lebih mungkin ditingkatkan ketika peserta didik diberi kesempatan untuk mengatur diri sendiri dan diajarkan strategi belajar metakognitif secara eksplisit. Downing (2009) menyatakan bahwa adanya hubungan yang signifikan antara prestasi akademik dan perubahan situasi metakognisi, serta ada perbedaan yang signifikan dalam kemampuan belajar dan pengembangan metakognitif.

\section{Simpulan dan Saran}

Implementasi RPP model PME menghadirkan situasi pembelajaran metakognitif, pemecahan masalah secara kolaboratif dan konstruktivis. Simpulan yang diperoleh sebagai hasil penelitian ini bahwa penerapan RPP model PME secara signifikan: (1) meningkatkan kinerja metakognitif peserta didik yang terjadi karena peserta didik harus melakukan kegiatan mandiri peserta didik (selfactivities) untuk membangun pengetahuan dasar mereka melalui kegiatan eksplorasi dan elaborasi pada fase planning, kegiatan pemecahan masalah secara kolaboratif pada fase monitoring, dan kegiatan self-evaluation melalui pengisian LKK-PME pada fase evaluating; (2) meningkatkan kinerja metakognitif peserta didik yang meliputi predicting outcomes, evaluating work, questioning by the teacher yang dimodifikasi menjadi questioning to the teacher, selfassessing, self-questioning, selecting strategies, using directed or selective thinking, using discourse, critiquing, dan revising, dan (3) meningkatkan kemampuan pemecahan masalah peserta didik secara kolaboratif. Oleh karena itu penerapan RPP model pembelajaran PME layak digunakan dalam kegiatan pembelajaran matematika untuk menciptakan pembelajaran yang sesuai dengan tuntutan kurikulum 2013,

Meskipun pada penelitian ini telah diperoleh hasil peningkatan yang signifikan terhadap variabel kinerja metakognitif dan kemampuan pemecahan masalah secara kolaboratif, namun masih perlu dikaji efek-efek lain dari penerapan RPP model pembelajaran PME diantaranya berkaitan dengan kemampuan pemecahan masalah secara individual dan peningkatan level metakognitif peserta didik, serta penerapan RPP pada mata pelajaran yang lain. Oleh karena itu peneliti merekomendasikan untuk diadakannya penelitian lanjutan tentang: (1) penerapan RPP model pembelajaran PME terhadap peningkatan kemampuan pemecahan masalah secara individual; (2) penerapan RPP model pembelajaran PME terhadap peningkatan level metakognitif peserta didik; dan (3) penerapan RPP model pembelajaran PME pada mata pelajaran yang lain (bukan hanya matematika).

\section{Referensi}

Ali, Riasat et al. (2010). Effect of Using Problem Solving Method in Teaching Mathematics on the Achievement of Mathematics Students. Asian Social Science, Vol. 6, No. 2 , pp. $67-72$

Amin, Ihdi, et al. (2017). Metacognitive Strategy and Problem Solving Ability on Mathematics Teaching-Learning Process of High School Students. 
Proceeding of ICMSE (International Conference on Mathematics, Science, and Education), Vol. 4, No. 1

Amin, Ihdi \& Mariani, Sc. (2017). PME Learning Model : The Conceptual Theoretical Study Of Metacognition Learning In Mathematics Problem Solving Based On Constructivism. IEJME - Mathematics Education, vol. 12(4), p. 333-352.

Amin, Ihdi \& Sukestiyarno. (2015). Analysis Metacognitive Skills on Mathematics Learning in Hitgh School. International Journal of Education and Research, Vol. 3, No. 3, pp. $213-222$.

Carlson, Marilyn P. and Bloom, Irene. (2005). The Cyclic Nature of Problem Solving: An Emergent Multidimensional Problem-SolvingFramework. Educational Studies in Mathematics, Vol. 58, No. 1 (2005), pp. 45-75. Published by: SpringerStable URL: http://www.jstor.org/stable/25047137 .Accessed: 28/12/2011.

Darling-Hammond, L. et al. (2003). The Learning Classroom: Theory into Practice. Stanford University: Annenberg/CPB. Tersedia: https://www.learner.org/ classroom/support/09_metacog.pdf

courses/learning

Downing K.J. (2009). Self-Efficacy And Metacognitive Development. The International Journal of Learning. Volume 16, Number 4. Tersedia: http:/ /Www.Learning-Journal.Com, Issn 1447-9494

Duncan, G., \& Met, M. (2010). STARTALK: From paper to practice. College Park, MD: National Foreign Language Center at the University of Maryland. Available at www.startalk.umd.edu/lesson_planning

Feist, Jess \& Feist, Gregory J. (2013). Teori Kepribadian (Theory of Personality, 7th ed). Jakarta: Salemba Humanika.

Gartmann, S. and Freiberg, M. (1993). Metacognition and Mathematical Problem Solving:Helping Students to Ask The Right Questions. Journal: The Mathematics Educator, Vol. 6, No. 1, pp. 9 - 13.

Ghasempour, Z., Bakar, M.D., \& Jahanshahloo. G.R. (2013). Innovation in Teaching and Learning through Problem Posing Tasks and Metacognitive Strategies. International Journal of Pedagogical Innovations, Vol 1, No. 1, pp. $53-62$.

Hoe, L.N., Shook Cheong, A.C., Lee Peng Yee, L.P. (2001). The Role of Metacognition in the Learning of Mathematics among Low-Achieving Students. Teaching and Learning Journal, Vol. 22, No. 2, pp. $18-30$.

Hurme, Tarja-Riitta. (2010). Metacognition in group problem solving-a quest for socially shared metacognition. Oulu: Faculty of Education, Department of Educational Sciences and Teacher Education, University of Oulu, Finland.

John, Peter D. (2006). Lesson planning and the student teacher: re-thinking the dominant model. Journal of Curriculum Studies ISSN 0022-0272, VOL. 38, NO. 4, p.483-498

Jones, Jane. (1998). Lesson planning: Towards purposeful learning and effective teaching. Encuentro. Revista de Investigación e Innovación en la clase de idiomas, 10, pp. 89-98.

Joyce, Bruce, Weil, Marsha, \& Calhoun, Emily. (2009). Models of Teaching (Model-model Pengajaran). Yogyakarta: Pustaka Pelajar

Kemdikbud. (2016). Silabus Silabus Mata Pelajaran Sekolah Menengah Atas/Madrasah Aliyah/Sekolah Menengah Kejuruan/Madrasah Aliyah Kejuruan (SMA/MA/SMK/MAK) Mata Pelajaran Matematika. Jakarta: Kemdikbud 
Lester Jr, F.K. (2013). Thoughts about Research on Mathematical Problem Solving Instruction. Jorunal: The Mathematics Enthusiast (TME), Vol. 10, No. $1 \& 2$, pp. $245-278$.

Lu, Hsin-Ke and Lin, Peng-Chun. (2017). A Study of the Impact of Collaborative Problem-Solving Strategies on Students' Performance of Simulation-Based Learning - A Case of Network Basic Concepts Course. International Journal of Information and Education Technology, Vol. 7, No. 5, May 2017

Muijs \& Reynolds. (2008). Effective Teaching. Yogyakarya: Rosdakarya.

Okoza, J. \& Aluede, O. (2013). Understanding metacognitive awareness among teachers in the school system: issues and benefits. Inkanyiso, Journal Humanistic \& Sosial Science, Vol. 5, No. 1.

Schneider, W. \& Lockl, K. (2002). The Development of Metacognitive Knowledge in Children and Adolescents. In Perfect, T. and Schwartz, B. (Eds.), Applied Metacognition. Cambridge, UK: Cambridge University Press.

Shrawder, Jack H. (2006). Planning a Successful Lesson Publisher/Editor, Teaching For Success South Lake Tahoe, CA jack@teachingforsuccess.com)

TEAL (Teaching Excellence in Adult Literacy). (2012). Just Write! Guide. Washington DC: American Institute for Research (AIR).

Toit, S Du. (2009) The Use of Metacognitive Strategies in The Teaching and Learning of Mathematics. Proceedings of the 15th Annual Congress of the Association for Mathematics Education of South Africa (AMESA) vol 1 p 9-21

Uno, H.B. (2009). Model Pembelajaran Menciptakan Proses Belajar Mengajar yang Kreatif dan Efektif. Jakarta: PT Bumi Aksara.

Yimer, Asmamaw \& Ellerton, Nerida F. (2006). Cognitive and Metacognitive Aspects of Mathematical Problem Solving: An Emerging Model Tersedia: Http://Www.Merga.Net.Au/Documents/RP672006.Pdf. Diuduh 26 April 2015

Yin, Khoo Yin \& Abdullah, Abdul Ghani Kanesan. (2013). The Collaborative Problem Solving Questionnaire: Validity and Reliability Test. International Journal of Academic Research in Business and Social Sciences January 2013, Vol. 3, No. 1.ISSN: 2222-6990. 